\title{
Serum vitamin D concentrations at dry-off and close-up predict increased postpartum urine ketone concentrations in dairy cattle
}

\author{
L. Wisnieski, J. L. Brown, (1) S. J. Holcombe, (1) J. C. Gandy, (i) and L. M. Sordillo* (i) \\ Department of Large Animal Clinical Sciences, College of Veterinary Medicine, Michigan State University, East Lansing 48824
}

\begin{abstract}
Vitamin D is commonly supplemented to dairy cows as vitamin $\mathrm{D}_{3}$ to support calcium homeostasis and in times of low sunlight exposure. Vitamin D has beneficial immunomodulatory and anti-inflammatory properties. Serum 25-hydroxyvitamin D $[25(\mathrm{OH}) \mathrm{D}]$ concentrations fluctuated during lactation, with the lowest concentrations measured in healthy cows within $7 \mathrm{~d}$ of calving. However, it is unknown if serum $25(\mathrm{OH}) \mathrm{D}$ concentrations measured during the previous lactation are associated with transition diseases or health risk factors in dairy cattle. We collected serum samples from 279 dairy cattle from 5 commercial dairy herds in Michigan at dry-off, close-up, and 2-10 d in milk (DIM). Vitamin $\mathrm{D}$ concentrations were determined by measuring serum $25(\mathrm{OH}) \mathrm{D}$ by radioimmunoassay. Total serum calcium was measured by colorimetric methods. Body condition scores (BCS) were assigned at the time of blood collection. Clinical disease incidence was monitored until 30 d postparturition. Separate bivariable logistic regression analyses were used to determine if serum $25(\mathrm{OH}) \mathrm{D}$ at dry-off, close-up, and 2-10 DIM was associated with various clinical diseases including mastitis, lameness, and uterine disorders (classified as metritis, retained placenta, or both) and increased urine ketone concentrations at $P<0.05$. Among all significant bivariable analyses, multivariable logistic regression analyses were built to adjust for potential confounding variables including parity, BCS, season, and calcium. Receiver operator characteristic (ROC) curve analyses were used to determine optimal concentrations of serum 25(OH)D. We found that higher serum $25(\mathrm{OH}) \mathrm{D}$ concentrations at dry-off and close-up predicted increased urine ketone concentrations in early lactation, even after adjustment for confounders. Alternatively, we found that lower serum $25(\mathrm{OH}) \mathrm{D}$ at 2-10 DIM was associated with uterine diseases. Optimal concentrations for serum 25(OH)D
\end{abstract}

Received March 11, 2019.

Accepted July 16, 2019.

*Corresponding author: sordillo@msu.edu at dry-off and close-up for lower risk of increased urine ketone concentrations were below 103.4 and $91.1 \mathrm{ng} /$ $\mathrm{mL}$, respectively. The optimal concentration for serum $25(\mathrm{OH}) \mathrm{D}$ at 2-10 DIM for uterine diseases was above $71.4 \mathrm{ng} / \mathrm{mL}$. These results indicate that serum $25(\mathrm{OH})$ $\mathrm{D}$ at dry-off and close-up may be a novel predictive biomarker for increased urine ketone concentrations during early lactation. Increased urine ketone concentrations are not necessarily harmful or diagnostic for ketosis but do indicate development of negative energy balance, metabolic stress, and increased risk of early lactation diseases. Predicting that dairy cattle are at increased risk of disease facilitates implementation of intervention strategies that may lower disease incidence. Future studies should confirm these findings and determine the utility of serum $25(\mathrm{OH}) \mathrm{D}$ concentrations as a predictive biomarker for clinical and subclinical ketosis.

Key words: dairy cow, vitamin D, transition disease, ketonuria

\section{INTRODUCTION}

The 2 major natural sources of vitamin D are ergocalciferol (vitamin $\mathrm{D}_{2}$ ) and cholecalciferol (vitamin $D_{3}$ ). Vitamin $D_{2}$ is synthesized in fungi and yeast and is mostly found in forages and the dead leaves of growing plants. Vitamin $\mathrm{D}_{3}$ is provided by animal sources (Miller, 1979). Like other mammals, dairy cattle synthesize $\mathrm{D}_{3}$ from sunlight (Miller, 1979) though sun exposure is limited by indoor housing. Vitamin D is commonly supplemented in dairy cattle feed in the form of vitamin $\mathrm{D}_{2}$ and $\mathrm{D}_{3}$ to support calcium homeostasis. Vitamin D, both ingested and absorbed through the skin, is converted to 25 -hydroxyvitamin D $[\mathbf{2 5}(\mathbf{O H}) \mathbf{D}]$ in the liver, and then to 1,25 dihydroxyvitamin D $[\mathbf{1 , 2 5}(\mathbf{O H}) \mathbf{2 D}]$ in the kidney (Horst et al., 1994). The $1,25(\mathrm{OH}) 2 \mathrm{D}$ form of vitamin $\mathrm{D}$ is the most biologically active and functions as a hormone and helps regulate calcium absorption (NRC, 2001). Typically, serum $25(\mathrm{OH}) \mathrm{D}$ concentrations in dairy cattle fall between 40 and $100 \mathrm{ng} / \mathrm{mL}$ (Sorge et al., 2013; Nelson et al., 2016; Holcombe et al., 2018). Supplementation of $30 \mathrm{IU}$ of vitamin $\mathrm{D} / \mathrm{kg}$ of $\mathrm{BW}$ is recommended for 
adult dairy cattle, which equals approximately 15,000 to 20,000 IU/d (Herdt and Stowe, 1991; NRC, 2001).

Scant data support the predictive utility of serum vitamin D concentrations for transition diseases in dairy cows or the associations between vitamin D supplementation and changes in disease incidence or severity. Given that vitamin D is an important immunomodulatory antioxidant and supports calcium homeostasis (Horst et al., 1994; Steingrimsdottir et al., 2005; Téllez-Pérez et al., 2012), it seems likely that serum vitamin $\mathrm{D}$ concentrations could be associated with risk of transition diseases. The NRC guidelines state that vitamin D deficiency was linked to lameness and pelvic fractures in cattle due to development of osteomalacia (NRC, 2001). Serum vitamin D concentrations predicted occurrence of clinical hypocalcemia or milk fever in early lactation dairy cows (Horst et al., 1994; Goff, 2006, 2008). However, the relationship between vitamin $\mathrm{D}$ treatment and the prevention of milk fever is complex. Vitamin D metabolites are generally most effective in preventing milk fever when administered between 1 and $4 \mathrm{~d}$ before calving. Therefore, accurate prediction of the calving date is critical (Sachs et al., 1977; Gast et al., 1979; DeGaris and Lean, 2008). The association between vitamin $\mathrm{D}$ treatment and prevention of milk fever is further complexed by the fact that DCAD in the diet affects how well vitamin D metabolites are absorbed (Weiss et al., 2015; Rodney et al., 2018). In a research dairy herd investigating effects of prepartum DCAD and nutritional sources of vitamin $\mathrm{D}$, Martinez et al. reported that feeding calcidiol rather than cholecalciferol reduced the incidence of both retained placenta and metritis (Martinez et al., 2018). Intramammary treatment by infusion of vitamin D into infected mammary gland quarters enhanced local immune function, decreased colonization by mastitiscausing bacteria, reduced SCC in milk, and reduced clinical symptoms of mastitis when compared with untreated cows (Lippolis et al., 2011; Téllez-Pérez et al., 2012).

Serum 25(OH)D concentrations fluctuated during the previous lactation, with highest values at dry-off, followed by close-up, and further decreasing to 2-10 DIM in healthy postpartum cows in commercial dairy herds (Sorge et al., 2013; Holcombe et al., 2018). Fresh cows had lower serum 25(OH)D concentrations compared with cows in other reproductive stages (Sorge et al., 2013). The relationship between serum vitamin D concentrations and dairy cattle disease incidence or risk remains unclear. Determining the associations between serum $25(\mathrm{OH}) \mathrm{D}$ concentrations during the lactation period and transition period diseases may clarify if $25(\mathrm{OH}) \mathrm{D}$ can be used as a biomarker for disease occurrence.
Our first objective was to determine if serum $25(\mathrm{OH})$ D concentrations measured at dry-off, close-up, and 2-10 DIM were associated with early lactation diseases, including mastitis, lameness, and uterine disorders (metritis, retained placenta, or both) or with increased urine ketone concentrations. Our second objective was to determine optimal concentrations of serum $25(\mathrm{OH})$ $\mathrm{D}$ at these time points in relation to disease risk and increased urine ketone concentrations. We hypothesized that higher serum 25(OH)D measured at dry-off and close-up would be associated with a lower risk of transition diseases.

\section{MATERIALS AND METHODS}

\section{Animals}

The Animal Use and Care Committee at Michigan State University (East Lansing) approved this study. Details concerning the original sample size calculation, study protocol, enrollment criteria at the herd level, and methods for follow-up are described in Wisnieski et al. (2019). Briefly, a total of 300 Holstein cows were selected from 5 Michigan commercial dairy herds, divided into cohorts containing 15 cows each, which were stratified by season. Cows in each cohort were randomly selected from the cows to be dried off that week and heifers were enrolled at the equivalent time before calving. Each cohort contained an equal number of cows in their first lactation, second lactation, and third or greater lactation. Cows were enrolled that were clinically healthy at the start of the study. Cows were excluded if they were lost to follow-up or did not calve. Health status was monitored from dry-off to 30 d postparturition using case definitions developed with herd health managers. Diagnoses were confirmed by a veterinarian or trained farm employee. For this study, clinical mastitis was diagnosed based on visible abnormalities of the milk within the first 30 DIM. Retained placenta was diagnosed when the fetal membranes were not expelled within $24 \mathrm{~h}$ of calving. Metritis was diagnosed based on transrectal palpation of a flaccid uterus that was not contracting normally and the presence of abnormal vaginal discharge within $21 \mathrm{~d}$ postcalving. Increased urine ketones were determined by measuring urine acetoacetate concentrations (Ketostix, Bayer Corporation, Elkhart, IN) of $\geq 1.5 \mathrm{mmol} / \mathrm{L}$ during the daily fresh checks while postpartum cows were 2-10 DIM.

\section{Measurement of 25(OH)D and Calcium}

The amount of vitamin D supplemented in feed by each farm is presented in Table 1. Blood samples were collected from the tail vein at time of dry-off, close-up, 
Table 1. Amount of vitamin D ( $\mathrm{kIU} / \mathrm{kg}$ of $\mathrm{DM})$ supplemented in feed by farm, time point, and parity

\begin{tabular}{lcccccc}
\hline & \multicolumn{5}{c}{ Farm } & \\
\cline { 2 - 5 } Item & 1 & 2 & 3 & 4 & 5 & Mean (SEM) \\
\hline $\begin{array}{l}\text { Dry-off } \\
\text { Heifer }\end{array}$ & 2.20 & 4.47 & 4.38 & 1.45 & 1.32 & $2.77(1.56)$ \\
Cow & 1.78 & 4.47 & 3.96 & 1.45 & 1.32 & $2.60(1.50)$ \\
Close-up & 2.73 & 9.30 & 2.87 & 1.45 & 1.32 & $3.54(3.30)$ \\
Heifer & 4.40 & 9.30 & 4.38 & 1.45 & 1.32 & $4.18(3.20)$ \\
Cow & 1.67 & 1.21 & 2.42 & 1.45 & 1.32 & $1.60(0.48)$ \\
$\begin{array}{l}\text { 2-10 DIM } \\
\text { Heifer }\end{array}$ & 1.67 & 1.21 & 2.42 & 1.45 & 1.32 & $1.60(0.48)$ \\
Cow & & & & & & \\
\hline
\end{tabular}

and 2-10 DIM. The sampling interval (mean \pm SEM) from dry-off to close-up was $33.4 \pm 0.78 \mathrm{~d}$, from closeup to calving was $15.03 \pm 0.46 \mathrm{~d}$, and from calving to 2-10 DIM was $7.54 \pm 0.20$ d. Serum was harvested and stored at $-20^{\circ} \mathrm{C}$ for batch analysis for 1 to 6 mo. The concentration of $25(\mathrm{OH}) \mathrm{D}$ (both vitamin $\mathrm{D}_{2}$ and $\mathrm{D}_{3}$ ) was measured by Heartland Assays (Iowa State University Research Park, Ames; Farrell et al., 2012). The Michigan State University Diagnostic Center for Population and Animal Health used colorimetric measurement to quantify total serum calcium using reagent from Beckman Coulter (Brea, CA). More information on the detection range, specificity, and inter- and intraassay coefficients of variation of the $25(\mathrm{OH}) \mathrm{D}$ assay is reported in Holcombe et al. (2018).

\section{Data Analysis}

Descriptive Analyses. Parity, season, and BCS were treated as categorical variables. Parity was a binary variable $(1=$ first lactation, $0=$ second or greater lactation). Season was based on the month the sample was collected (March, April, May = spring; June, July, August $=$ summer; September, October, November $=$ fall; December, January, February $=$ winter). Body condition score was rated on the 5-point scale in 0.5 increments (Kristensen, 1986). Categories of BCS were based on the distribution of the data if possible. However, BCS at dry-off had a narrower distribution so was made into a binary variable $(1=3.5$ or $4.0,0=<3.5$ or $>4.0)$. The categories for BCS at close-up and $2-10$ DIM were as follows: $1=<2.5,2=3.0,3=3.5,4=4.0$ and greater. Clinical transition period diseases included mastitis, lameness, retained placenta, and metritis. Increased urine ketone concentration was also analyzed as an outcome. Due to low disease incidence, metritis and retained placenta were grouped together under "uterine diseases."

Summary statistics for $25(\mathrm{OH}) \mathrm{D}$ by disease status and covariables (parity, season, sample period, BCS, and farm) were reported. The association between the mean serum $25(\mathrm{OH}) \mathrm{D}$ concentration and the mean feed concentration of vitamin $\mathrm{D}_{3}$ on each farm were assessed via a Spearman correlation. Concentrations of serum $25(\mathrm{OH}) \mathrm{D}$ were compared between normal and increased urine ketone concentrations or between diseased versus nondiseased at each time point using 2 -sample $t$-tests with an adjustment for unequal variances and unequal sample sizes (Satterthwaite approximation). Mixed linear regression with a random intercept for herd was used to assess the association between serum $25(\mathrm{OH})$ $\mathrm{D}$ concentrations measured at each time point and projected mature equivalent $305-\mathrm{d}$ milk production (ME305).

Bivariable and Multivariable Analyses. Logistic regression models were used to assess the association between serum 25(OH)D and early lactation diseases using the melogit command in Stata 14.2 (StataCorp, $2015)$. We tested the relationship between $25(\mathrm{OH}) \mathrm{D}$ measured at dry-off, close-up, and 2-10 DIM with multiple disease outcomes, including mastitis, lameness, and uterine disorders and increased urine ketone concentrations. Total serum calcium and $25(\mathrm{OH}) \mathrm{D}$ were treated as continuous unless linearity assumptions were violated (not linearly related to the dependent variable in the log odds scale). If assumptions were violated, calcium or $25(\mathrm{OH}) \mathrm{D}$ (or both) were either transformed by a function (e.g., log, square root, square) or made into a categorical variable.

Bivariable analyses were performed to test the association between $25(\mathrm{OH}) \mathrm{D}$ and each disease outcome at the 3 time points ( 3 models per disease outcome). Multivariable analyses were performed to adjust for potential confounders for each disease outcome and time point combination that had a statistically significant $(P$ $<0.05)$ association with serum $25(\mathrm{OH}) \mathrm{D}$ concentrations in the bivariable analyses. In addition to $25(\mathrm{OH}) \mathrm{D}$, we included other potential confounders including parity, season, BCS, and total serum calcium concentrations in variable selection. Confounders were retained in the 
model if they were significant at an $\alpha$ of 0.10 or if they changed any other parameter estimates by greater than $20 \%$ when removed (Bursac et al., 2008; Hosmer et al., 2013). A backward elimination procedure was used to select all fixed effects. To account for the hierarchical structure of the data, the significance of random intercepts for the farm and cohort levels were tested using likelihood ratio tests. The final multivariable models were assessed for goodness-of-fit using the HosmerLemeshow deciles of risk test and problematic covariate patterns were evaluated using diagnostic graphs for leverage and deviance (Hosmer et al., 2013).

Receiver Operator Characteristic Analysis. Receiver operator characteristic (ROC) analyses were conducted to assess the discriminant ability of each multivariable analysis and statistically significant bivariable analysis. Discriminant ability is the capability of the model to classify those that will get the disease (or adverse outcome) versus those that will not (Hosmer et al., 2013). The roctg command in Stata was used to create a plot of sensitivity versus 1-specificity and calculate the optimum critical threshold for distinguishing between diseased and nondiseased individuals (Greiner et al., 2000; Reichenheim, 2002; Dohoo et al., 2012).

For each significant bivariable analysis, a range of potential critical thresholds for serum $25(\mathrm{OH}) \mathrm{D}$ concentrations were calculated. Sensitivity, specificity, AUC, and likelihood ratios were determined for each threshold. Likelihood ratio positive $(\mathbf{L R}+)$ values are defined as the probability of a diseased individual having a result below/above the threshold relative to the probability of the same result in a nondiseased individual (Dohoo et al., 2012).

\section{RESULTS}

\section{Descriptive Analyses}

Twenty-one cows were excluded from the study including 16 cows that were missing data for all 3 time points, 3 cows lost to follow-up, one cow diagnosed with lameness on the date of dry-off, and one cow that did not calve, resulting in a total of 279 cows. Descriptive statistics for serum $25(\mathrm{OH}) \mathrm{D}$ concentrations by parity, season, sample period, BCS, and farm are shown in Table 2. Summary statistics for serum 25(OH)D concentrations by disease status and sample period are shown in Tables 3 and 4. Spearman correlations showed a significant negative correlation $\left(\mathrm{r}_{\mathrm{s}}=-0.34, P<0.05\right)$ between the mean serum $25(\mathrm{OH}) \mathrm{D}$ concentrations and mean vitamin $\mathrm{D}_{3}$ supplemented in feed by farm. Spearman correlations showed significant positive correlations between $25(\mathrm{OH}) \mathrm{D}$ and calcium concentrations at dry-off $\left(\mathrm{r}_{\mathrm{s}}=0.15, P=0.01\right)$ and DIM $2-10\left(\mathrm{r}_{\mathrm{s}}=0.27\right.$, $P<0.01)$, but not at close-up $\left(\mathrm{r}_{\mathrm{s}}=0.14, P=0.14\right)$. Mixed linear regression results showed no association between serum $25(\mathrm{OH}) \mathrm{D}$ concentrations at dry-off $(P$ $=0.94)$, close-up $(P=0.60)$, or DIM $2-10(P=0.94)$ with ME305.

\section{Bivariable and Multivariable Analyses}

The bivariable analyses showed significant associations of serum $25(\mathrm{OH}) \mathrm{D}$ concentrations with 2 health outcomes: increased urine ketone concentrations and uterine diseases. Serum 25(OH)D concentrations at dry-off [odds ratio $(\mathbf{O R})=1.02, P<0.01$ ] and closeup $(\mathrm{OR}=1.02, P<0.01)$ were positively associated with increased urine ketone concentrations, but serum $25(\mathrm{OH}) \mathrm{D}$ concentrations at $2-10$ DIM were not associated with increased urine ketone concentrations (OR $=1.00, P=0.99)$. Serum $25(\mathrm{OH}) \mathrm{D}$ concentrations at 2-10 DIM were inversely associated with uterine disorders $(\mathrm{OR}=0.9997, P<0.01)$, but serum $25(\mathrm{OH}) \mathrm{D}$ concentrations at dry-off $(\mathrm{OR}=0.9999, P=0.98)$ and close-up $(\mathrm{OR}=0.9999, P=0.11)$ were not associated with uterine disorders. Serum $25(\mathrm{OH}) \mathrm{D}$ concentrations were not significantly associated with mastitis or lameness at any time point in logistic regression analyses, although $25(\mathrm{OH}) \mathrm{D}$ was inversely related to lameness in descriptive analyses $(P<0.05$; Tables 4 and 5$)$.

Multivariable analyses were performed for the 3 bivariable analyses where serum $25(\mathrm{OH}) \mathrm{D}$ concentrations were significantly related to the outcome: $25(\mathrm{OH})$ $\mathrm{D}$ at dry-off and increased urine ketone concentrations, $25(\mathrm{OH}) \mathrm{D}$ at close-up and increased urine ketone concentrations, and $25(\mathrm{OH}) \mathrm{D}$ at $2-10$ DIM and uterine disorders. The results of the multivariable analyses are described in Table 5. The final multivariable model for increased urine ketone concentrations and $25(\mathrm{OH}) \mathrm{D}$ at dry-off included $25(\mathrm{OH}) \mathrm{D}$, BCS, parity, and season. Even after adjustment for covariates, greater $25(\mathrm{OH}) \mathrm{D}$ concentrations at dry-off were associated with a greater risk of having increased urine ketone concentrations $(\mathrm{OR}=1.02, P<0.01)$. The final model for increased urine ketone concentrations and $25(\mathrm{OH}) \mathrm{D}$ at close-up contained $25(\mathrm{OH}) \mathrm{D}$ and parity after variable selection. Greater serum 25(OH)D concentrations at close-up were associated with a greater risk of having increased urine ketone concentrations $(\mathrm{OR}=1.02, P=0.01)$. The model for uterine disorders and $25(\mathrm{OH}) \mathrm{D}$ at $2-10$ DIM included 25(OH)D, calcium, BCS, and season. Serum $25(\mathrm{OH}) \mathrm{D}$ concentrations were transformed by the square function and calcium was treated as a categorical variable to meet linearity assumptions (on the log odds scale). Higher serum 25(OH)D concentrations were associated with lower odds of uterine diseases (OR 
Table 2. Descriptive statistics for vitamin D $(\mathrm{ng} / \mathrm{mL})$ concentration by parity, season, sample period, and BCS ( $\mathrm{n}=279$ cows)

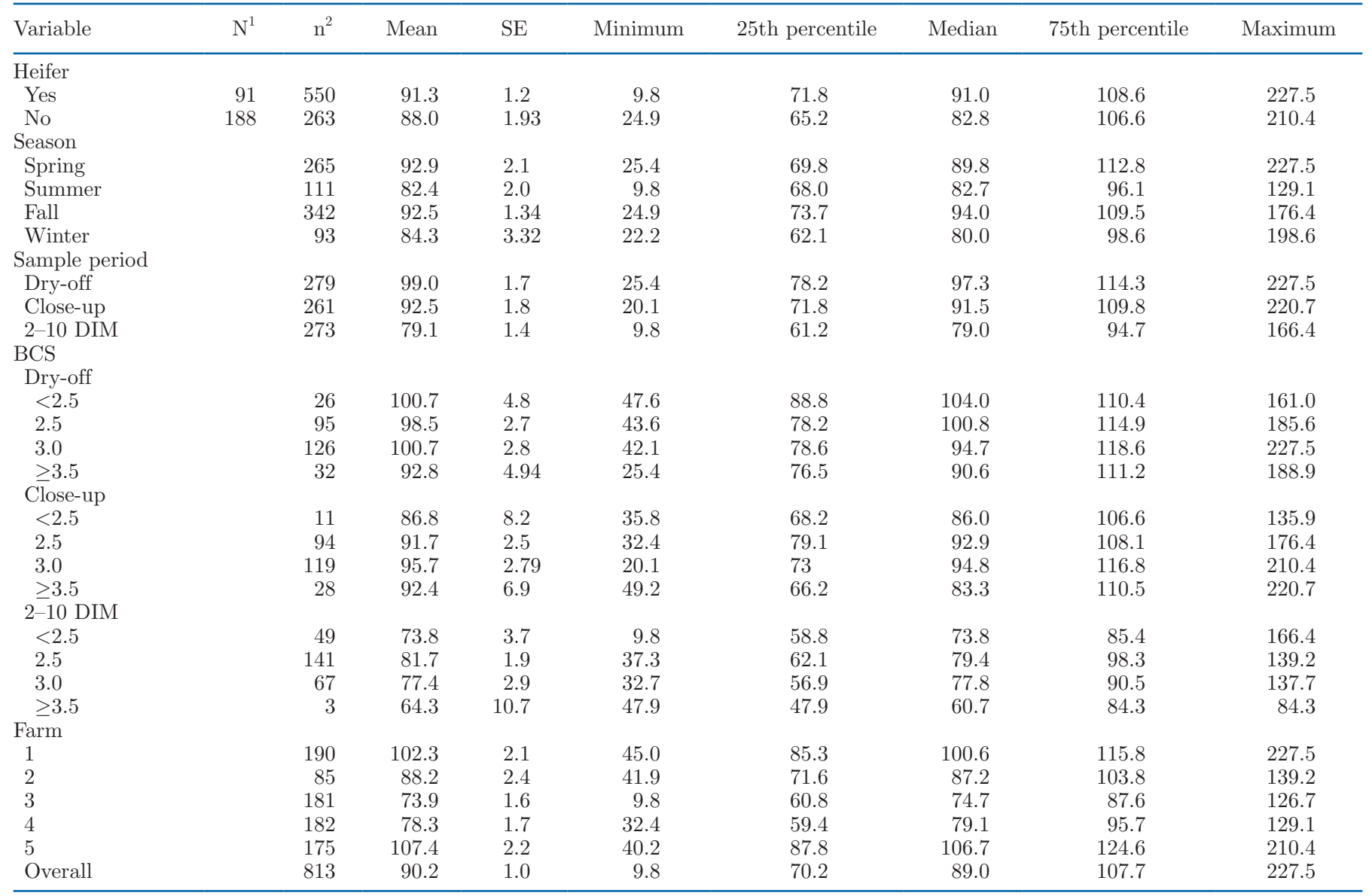

${ }^{1}$ Number of cows.

${ }^{2}$ Number of samples.

$=0.9998, P<0.01)$. Higher calcium concentrations were associated with lower odds of uterine diseases, with the lowest odds at calcium levels greater than 9.8 $\mathrm{mg} / \mathrm{dL}(\mathrm{OR}=0.07$ compared with reference group of calcium levels less than $9.1 \mathrm{mg} / \mathrm{dL}, P<0.01)$. Random intercepts for farm and cohort were both insignificant in all analyses so were excluded (Hosmer et al., 2013). Hosmer-Lemeshow tests indicated that all 3 final multivariable models had acceptable goodness-of-fit $(P>$ $0.05)$.

\section{ROC Curve Analyses for Serum 25(OH)D}

Potential critical thresholds of serum 25(OH)D and their respective sensitivity and specificity are presented in Table 6. Higher serum 25(OH)D levels at dry-off and close-up were associated with a higher risk of increased urine ketone concentrations. Therefore, animals with levels below the critical threshold had a lower risk. The optimum thresholds for serum $25(\mathrm{OH}) \mathrm{D}$ at dry-off and close-up for normal urine ketone concentrations was below 103.4 and $91.1 \mathrm{ng} / \mathrm{mL}$, respectively. The LR+ values for increased urine ketone concentrations were 1.4 and 1.7 for dry-off and close-up. The LR+ value for increased urine ketone concentrations at close-up can be interpreted as that animals at or above this threshold of serum $25(\mathrm{OH}) \mathrm{D}$ have almost double the risk of having increased urine ketone concentrations compared with those below the threshold (Dohoo et al., 2012). Alternatively, for uterine disease at 2-10 DIM, lower serum 25(OH)D levels were associated with higher disease incidence, so animals with levels above the threshold were more likely to have uterine diseases. The optimum threshold for uterine diseases at 2-10 DIM was above $71.4 \mathrm{ng} / \mathrm{mL}$ with a $\mathrm{LR}+$ of 1.8 for those below this threshold.

\section{DISCUSSION}

This is the first study to find that higher serum $25(\mathrm{OH}) \mathrm{D}$ concentrations measured at dry-off and closeup were associated with increased urine ketone concen- 
trations postcalving at between 2-10 DIM. Martinez et al. (2018) found that feeding calcidiol, a vitamin D precursor, tended to increase the incidence of hyperketonemia. However, Martinez et al. (2018) noted that the cows fed calcidiol had similar daily risk estimates compared with the other treatment groups. Daily risk estimates included hyperketonemia incidence, duration of hyperketonemia, and relapse, suggesting that caldiciol reduced the severity of hyperketonemia or helped prevent relapses.

One potential reason for finding that higher serum $25(\mathrm{OH}) \mathrm{D}$ predicted increased urine ketone concentrations in the current study is that greater availability of serum $25(\mathrm{OH}) \mathrm{D}$ concentrations may support greater ketone body formation. Rodney et al. (2019) determined that blood calcidiol was positively associated with concentrations of BHB. Calcidiol and calcium concentrations were positively associated with nonesterified fatty acids and glucose concentrations, supporting their role in energy metabolism (Martinez et al., 2014; Rodney et al., 2019).

The presence of ketones in the blood or urine alone may not be harmful because ketone production is an efficient means of transporting energy to peripheral tissues when demands for glucose are high (Duffield, 2000). Increased urine ketone concentrations indicate metabolic stress and development of negative energy balance that can occur during the early postpartum period. Urine ketone concentrations are monitored quickly and inexpensively in the stall in early postpartum dairy cows as a screening test for hyperketonemia and possible ketosis. The direct quantitative correlation between urine ketones and serum ketones is unknown. Hyperketonemia is a known risk factor for several early lactation diseases, impaired immune function, and may be associated with negative effects on production parameters (McArt et al., 2012). Future work should include investigating the mechanism behind the relationship between higher serum 25(OH)D concentrations and increased risk for increased urine ketone concentrations and determine if serum $25(\mathrm{OH})$ $\mathrm{D}$ concentrations are also associated with the risk and duration of ketosis, including clinical (primary and secondary) and subclinical ketosis.

The results of the current study suggest serum $25(\mathrm{OH}) \mathrm{D}$ concentrations at dry-off may provide a biomarker for the development of increased urine ketone concentrations in dairy cattle postpartum. This would have implications for improving animal welfare and production because elevated concentrations of urine ketones may be related to increased incidence and severity of other early lactation diseases that adversely

Table 3. Vitamin D (ng/mL) concentrations by disease status and the presence of increased urine ketones $(\mathrm{n}=279$ cows $)$

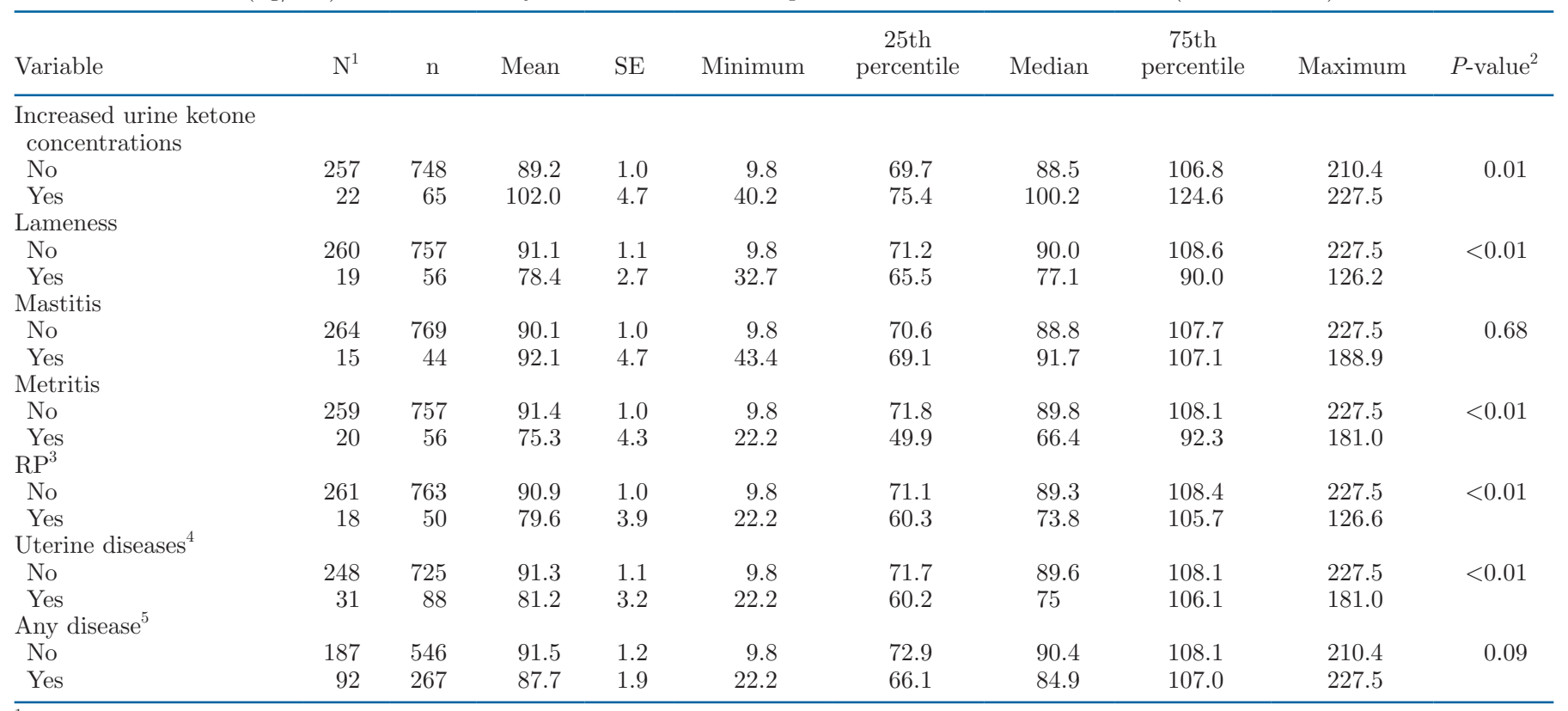

${ }^{1}$ Number of cows.

${ }^{2}$ Two-sample $t$-test for equal means. Adjusted for heterogeneous variances and unequal sample sizes.

${ }^{3}$ Retained placenta.

${ }^{4}$ Includes retained placenta (RP) and metritis.

${ }^{5}$ Includes increased urine ketone concentrations, lameness, mastitis, metritis, RP, milk fever, pneumonia, and displaced abomasum. 
Table 4. Vitamin D (ng/mL) concentrations by disease status and sample period $(\mathrm{n}=279$ cows $)$

\begin{tabular}{|c|c|c|c|c|c|c|c|c|c|}
\hline Variable & $\mathrm{N}^{1}$ & Mean & $\mathrm{SE}$ & Minimum & $\begin{array}{c}25 \text { th } \\
\text { percentile }\end{array}$ & Median & $\begin{array}{c}75 \text { th } \\
\text { percentile }\end{array}$ & Maximum & $P$-value ${ }^{2}$ \\
\hline \multicolumn{10}{|c|}{$\begin{array}{l}\text { Increased urine ketone } \\
\text { concentrations }\end{array}$} \\
\hline No & 257 & 97.4 & 1.7 & 25.4 & 77.6 & 96.2 & 112.5 & 198.6 & \\
\hline Yes & 22 & 118.2 & 8.6 & 61.7 & 90.3 & 118.1 & 130.2 & 227.5 & \\
\hline Close-up & & & & & & & & & 0.046 \\
\hline 2-10 DIM & & & & & & & & & 0.98 \\
\hline No & 251 & 79.1 & 1.5 & 9.8 & 61.2 & 78.7 & 94.7 & 166.4 & \\
\hline Yes & 22 & 79.2 & 5.1 & 40.2 & 56.1 & 79.5 & 100.2 & 121.8 & \\
\hline \multicolumn{10}{|l|}{ Lameness } \\
\hline Dry-off & & & & & & & & & 0.01 \\
\hline No & 260 & 99.7 & 1.8 & 25.4 & 80.0 & 98.4 & 115.2 & 227.5 & \\
\hline Yes & 19 & 86.0 & 4.5 & 59.2 & 68.3 & 82.4 & 101.6 & 126.2 & \\
\hline Yes & 18 & 70.1 & 4.7 & 32.7 & 56.3 & 68.8 & 84.8 & 104.3 & \\
\hline \multicolumn{10}{|l|}{ Mastitis } \\
\hline Dry-off & & & & & & & & & 0.51 \\
\hline No & 264 & 98.7 & 1.6 & 25.4 & 78.4 & 97.4 & 113.6 & 227.5 & \\
\hline Yes & 15 & 104.9 & 9.1 & 61.7 & 77.0 & 95.9 & 122.6 & 188.9 & \\
\hline Close-up & & & & & & & & & 0.90 \\
\hline No & 247 & 92.5 & 1.9 & 20.1 & 71.6 & 92.8 & 111.0 & 220.7 & \\
\hline Yes & 14 & 91.6 & 8.5 & 56.5 & 71.8 & 87.6 & 109.0 & 164.9 & \\
\hline 2-10 DIM & & & & & & & & & 0.91 \\
\hline No & 258 & 79.1 & 1.5 & 9.8 & 61.2 & 78.9 & 94.7 & 166.4 & \\
\hline Yes & 15 & 79.9 & 6.8 & 43.4 & 59.7 & 84.1 & 97.8 & 139.2 & \\
\hline \multicolumn{10}{|l|}{ Metritis } \\
\hline Dry-off & & & & & & & & & 0.58 \\
\hline No & 259 & 99.4 & 1.8 & 25.4 & 79.7 & 97.9 & 114.3 & 227.5 & \\
\hline No & 261 & 99.4 & 1.8 & 25.4 & 78.6 & 96.4 & 114.3 & 227.5 & \\
\hline Yes & 18 & 93.4 & 6.0 & 47.0 & 63.5 & 101.8 & 111.8 & 126.6 & \\
\hline \multicolumn{9}{|l|}{ Close-up } & 0.28 \\
\hline No & 247 & 92.9 & 1.9 & 20.1 & 71.8 & 92.8 & 110.2 & 220.7 & \\
\hline Yes & 14 & 85.9 & 5.9 & 44.0 & 68.3 & 87.0 & 104.7 & 118.1 & \\
\hline 2-10 DIM & & & & & & & & & $<0.01$ \\
\hline No & 255 & 80.4 & 1.5 & 9.8 & 61.9 & 79.7 & 95.8 & 166.4 & \\
\hline Yes & 18 & 61.0 & 5.5 & 22.2 & 43.4 & 60.2 & 73.0 & 125.1 & \\
\hline \multicolumn{10}{|l|}{ Uterine diseases $^{4}$} \\
\hline Dry-off & & & & & & & & & 0.88 \\
\hline No & 248 & 99.1 & 1.8 & 25.4 & 79.0 & 96.1 & 114.2 & 227.5 & \\
\hline Yes & 31 & 98.2 & 5.7 & 43.6 & 66.6 & 105.7 & 116.3 & 181 & \\
\hline \multicolumn{9}{|l|}{ Close-up } & 0.08 \\
\hline No & 235 & 93.4 & 1.9 & 20.1 & 72.8 & 93.2 & 110.2 & 220.7 & \\
\hline Yes & 26 & 83.9 & 4.9 & 44.0 & 66.2 & 81.4 & 105.3 & 135.6 & \\
\hline 2-10 DIM & & & & & & & & & $<0.01$ \\
\hline No & 242 & 81.3 & 1.5 & 9.8 & 63.0 & 81.7 & 96.5 & 166.4 & \\
\hline Yes & 31 & 61.8 & 3.7 & 22.2 & 47.4 & 60.1 & 75.4 & 125.1 & \\
\hline \multicolumn{10}{|l|}{ Any disease ${ }^{5}$} \\
\hline Dry-off & & & & & & & & & 0.94 \\
\hline No & 186 & 99.1 & 2.0 & 25.4 & 81.0 & 97.6 & 112.5 & 198.6 & \\
\hline Yes & 93 & 98.8 & 3.3 & 43.6 & 76.0 & 96.3 & 117.2 & 227.5 & \\
\hline
\end{tabular}


Table 4 (Continued). Vitamin D $(\mathrm{ng} / \mathrm{mL})$ concentrations by disease status and sample period $(\mathrm{n}=279$ cows $)$

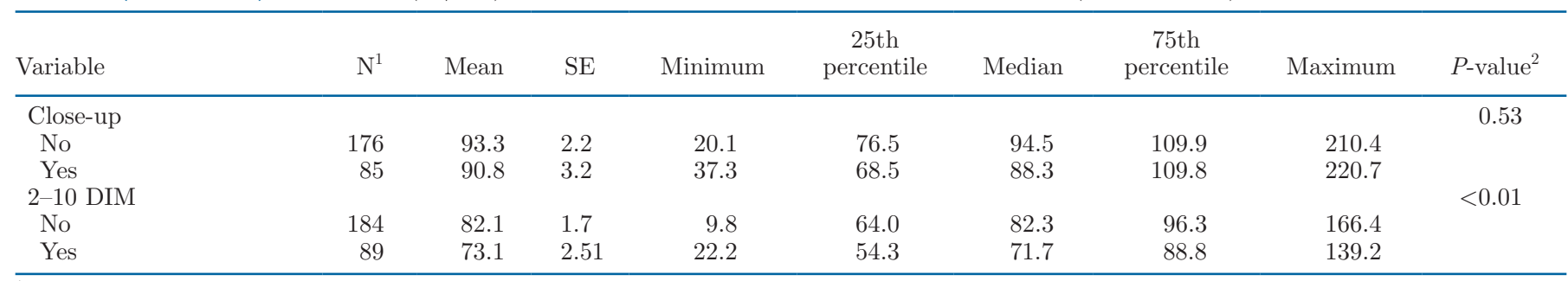

${ }^{1}$ Number of cows.

${ }^{2}$ Two-sample $t$-test for equal means. Adjusted for heterogeneous variances and unequal sample sizes.

${ }^{3} \mathrm{RP}=$ retained placenta.

${ }^{4}$ Includes RP and metritis.

${ }^{5}$ Includes increased urine ketone concentrations, lameness, mastitis, metritis, RP, milk fever, pneumonia, and displaced abomasum.

affect milk production (Duffield, 2000; McArt et al., 2012). In the current study, the ROC values for $25(\mathrm{OH})$ $\mathrm{D}$ at dry-off and close-up were $<0.70$ (0.64 and 0.67, respectively), which is considered poor predictive ability (Hosmer et al., 2013). This indicates that even though
$25(\mathrm{OH}) \mathrm{D}$ concentrations were significantly predictive of increased urine ketone concentrations a considerable number of cows still were miscategorized as "at-risk" or "not at-risk." Future studies should verify the predictive ability of $25(\mathrm{OH}) \mathrm{D}$ to determine increased urine

Table 5. Summary of multivariable analyses $(\mathrm{n}=279$ cows $)$

\begin{tabular}{|c|c|c|c|c|c|c|c|}
\hline $\begin{array}{l}\text { Transition period } \\
\text { disease }\end{array}$ & Sample period & Variable & $\mathrm{ROC}^{1}$ & $\begin{array}{l}\text { Odds } \\
\text { ratio }\end{array}$ & $\begin{array}{c}95 \% \\
\text { CI }\end{array}$ & $\mathrm{SE}$ & $P$-value \\
\hline $\begin{array}{l}\text { Increased urine } \\
\text { ketone } \\
\text { concentrations }\end{array}$ & Dry-off $(\mathrm{n}=279)$ & $\begin{array}{l}\text { Vitamin D } \\
\text { BCS of } 3.5 \text { or } 4.0^{2} \\
\text { Heifer } \\
\text { Season } \\
\text { Spring (referent) } \\
\text { Summer } \\
\text { Fall } \\
\text { Winter } \\
\text { Intercept }\end{array}$ & 0.80 & $\begin{array}{l}1.02 \\
0.33 \\
0.26 \\
\\
\\
0.42 \\
0.64 \\
3.09 \\
0.02\end{array}$ & $\begin{array}{l}1.00-1.03 \\
0.11-0.99 \\
0.07-1.00 \\
\\
0.05-3.69 \\
0.19-2.15 \\
0.97-9.87 \\
0.003-0.14\end{array}$ & $\begin{array}{l}0.01 \\
0.19 \\
0.18 \\
\\
\\
0.47 \\
0.40 \\
1.83 \\
0.02\end{array}$ & $\begin{array}{l}0.01 \\
0.049 \\
0.050 \\
0.06 \\
\\
0.44 \\
0.47 \\
0.06 \\
<0.01\end{array}$ \\
\hline $\begin{array}{l}\text { Increased urine } \\
\text { ketone } \\
\text { concentrations }\end{array}$ & Close-up $(\mathrm{n}=261)$ & $\begin{array}{l}\text { Vitamin D } \\
\text { Heifer } \\
\text { Intercept }\end{array}$ & 0.67 & $\begin{array}{l}1.02 \\
0.32 \\
0.002\end{array}$ & $\begin{array}{l}1.00-1.04 \\
0.09-1.16 \\
0.00009-0.05\end{array}$ & $\begin{array}{l}0.01 \\
0.21 \\
0.003\end{array}$ & $\begin{array}{l}0.010 \\
0.08 \\
0.000\end{array}$ \\
\hline Uterine diseases $^{3}$ & $2-10$ DIM $(\mathrm{n}=272)$ & $\begin{array}{l}\text { Vitamin } \mathrm{D}^{4} \\
\text { BCS } \\
<3.0 \text { (referent) } \\
3.0 \\
>3.0 \\
\text { Calcium } \\
<9.1 \mathrm{mg} / \mathrm{dL} \text { (referent) } \\
9.1 \text { to }<9.4 \mathrm{mg} / \mathrm{dL} \\
9.4 \text { to }<9.6 \mathrm{mg} / \mathrm{dL} \\
9.6 \text { to }<9.8 \mathrm{mg} / \mathrm{dL} \\
9.8 \mathrm{mg} / \mathrm{dL} \text { and greater } \\
\text { Season } \\
\text { Spring (referent) } \\
\text { Summer } \\
\text { Fall } \\
\text { Winter } \\
\text { Intercept }\end{array}$ & 0.83 & $\begin{array}{l}0.9998 \\
\\
0.78 \\
0.18\end{array}$ & $\begin{array}{l}0.99956-0.99992 \\
0.28-2.17 \\
0.04-0.75\end{array}$ & $\begin{array}{l}0.0001 \\
0.41 \\
0.13\end{array}$ & $\begin{array}{c}<0.01 \\
0.052 \\
\\
0.63 \\
0.02 \\
<0.01 \\
\\
0.03 \\
0.03 \\
0.01 \\
0.02 \\
0.06 \\
\\
0.02 \\
0.16 \\
0.03 \\
0.01\end{array}$ \\
\hline
\end{tabular}

\footnotetext{
${ }^{1}$ Receiver operator characteristic curve (calculated from the whole model).

${ }^{2}$ Compared with a BCS $<3.5$ or BCS $>4.0$.

${ }^{3}$ Includes retained placenta and metritis.

${ }^{4}$ Vitamin D was transformed (vitamin $\mathrm{D}_{2}$ ) to meet linearity assumptions.
} 
ketone concentrations and explore the costs and benefits of implementing serum $25(\mathrm{OH}) \mathrm{D}$ as a monitoring biomarker.

Lower serum $25(\mathrm{OH}) \mathrm{D}$ concentrations measured at 2-10 DIM were associated with uterine diseases (metritis, retained placenta, or both). At calving, serum $25(\mathrm{OH}) \mathrm{D}$ concentrations increase rapidly in response to increased calcium demands for lactation, then start to decrease a few days after calving (Goff et al., 1991; Horst et al., 1994). Cows with metritis and retained placenta had lower serum 25(OH)D concentrations, which could potentially be due to an activated immune system in response to uterine disease development. The vitamin D signaling pathway is active in cows and has a role in the acute phase response (Lippolis et al., 2011; Nonnecke et al., 2014). Nonnecke et al. (2014) reported reduced serum $25(\mathrm{OH}) \mathrm{D}$ concentrations in calves after experimental infection with bovine diarrhea virus. Sorge et al. (2013) found that cows seropositive for Mycobacterum avium ssp. paratuberculosis also had lower serum 25(OH)D concentrations. Serum 25(OH) $\mathrm{D}$ concentrations could potentially be used as a diagnostic biomarker for retained placenta and metritis in postpartum dairy cattle. However, additional investigations correlating serum $25(\mathrm{OH}) \mathrm{D}$ concentrations before development of uterine diseases are warranted.

Impaired calcium and vitamin D metabolism could also increase the risk for retained placenta and metritis.
Multiple studies have demonstrated the link between hypocalcemia and increased risk for retained placenta and metritis in cattle (Curtis et al., 1983; Gröhn et al., 1990; Martinez et al., 2012; Neves et al., 2018). Hypocalcemia negatively affects the immune system of dairy cows by impairing neutrophil function, which compromises cellular oxidative burst and phagocytic activities against bacteria (Martinez et al., 2012; Martinez et al., 2014). 1,25(OH)2D regulates both the innate and the adaptive immune system of the dairy cow (Waters et al., 2003; Nelson et al., 2010, 2011). The vitamin D signaling pathway can be exploited to improve the cow's response to bacterial infection as shown in Lippolis et al. (2011), which demonstrated that acute mammary infections can be successfully treated with $25(\mathrm{OH})$ D3. It is possible that the relationship between serum $25(\mathrm{OH}) \mathrm{D}$ and uterine diseases is bi-directional.

In the present study, we found no association between serum $25(\mathrm{OH}) \mathrm{D}$ concentrations and projected milk production (ME305). However, Hibbs and Conrad (1983) found that cows fed vitamin $\mathrm{D}_{2}$ had significantly greater milk production compared with cows that were not supplemented with vitamin $\mathrm{D}_{2}$. In addition, Wallis (1938) experimentally induced vitamin D deficiency in dairy cattle and established a rapid decrease in milk production. When cows fail to meet calcium demands for milk production through increased bone and intestinal calcium absorption, they can develop hypocalcemia

Table 6. Receiver operator characteristic (ROC) curve determination of critical serum 25-hydroxyvitamin D thresholds as predictors of diseases in early lactation dairy cows $(n=279$ cows $)$

\begin{tabular}{|c|c|c|c|c|c|c|c|c|}
\hline $\begin{array}{l}\text { Transition period } \\
\text { disease }\end{array}$ & Sample period & $\mathrm{ROC}$ & $\begin{array}{l}\text { Critical } \\
\text { threshold } \\
(\mathrm{ng} / \mathrm{mL})\end{array}$ & $\begin{array}{l}\mathrm{Se}^{1} \\
(\%)\end{array}$ & $\begin{array}{c}95 \% \text { CI } \\
\text { for } \\
\text { sensitivity }\end{array}$ & $\begin{array}{l}\mathrm{Sp}^{2} \\
(\%)\end{array}$ & $\begin{array}{c}95 \% \text { CI } \\
\text { for } \\
\text { specificity }\end{array}$ & $\mathrm{LR}+{ }^{3}$ \\
\hline \multirow[t]{2}{*}{$\begin{array}{l}\text { Increased urine ketone } \\
\text { concentrations }\end{array}$} & Dry-off $(\mathrm{n}=279)$ & 0.67 & $\begin{array}{c}83.5 \\
93.5 \\
103.5^{4} \\
113.5 \\
123.5\end{array}$ & $\begin{array}{l}81.8 \\
68.2 \\
59.1 \\
54.6 \\
45.5\end{array}$ & $\begin{array}{l}81.5-82.1 \\
67.9-68.5 \\
58.8-59.4 \\
54.3-45.2 \\
45.2-45.8\end{array}$ & $\begin{array}{l}31.1 \\
45.5 \\
58.8 \\
76.3 \\
86.4\end{array}$ & $\begin{array}{l}30.8-31.4 \\
45.2-45.8 \\
58.5-59.1 \\
76.0-76.6 \\
86.2-86.6\end{array}$ & $\begin{array}{l}1.2 \\
1.3 \\
1.4 \\
2.3 \\
3.3\end{array}$ \\
\hline & Close-up $(\mathrm{n}=261)$ & 0.64 & $\begin{array}{c}79.1 \\
89.1 \\
99.1^{4} \\
109.1 \\
119.1\end{array}$ & $\begin{array}{l}76.2 \\
76.2 \\
61.9 \\
47.6 \\
33.3\end{array}$ & $\begin{array}{l}75.9-76.5 \\
75.9-76.5 \\
61.5-62.2 \\
47.2-48.0 \\
32.9-33.7\end{array}$ & $\begin{array}{l}32.9 \\
47.1 \\
60.8 \\
75.4 \\
85.4\end{array}$ & $\begin{array}{l}32.5-33.3 \\
46.7-47.5 \\
60.4-61.1 \\
75.1-75.7 \\
85.1-85.7\end{array}$ & $\begin{array}{l}1.1 \\
1.4 \\
1.6 \\
1.9 \\
2.4\end{array}$ \\
\hline Uterine disesases $^{5}$ & $2-10$ DIM $(\mathrm{n}=272)$ & 0.74 & $\begin{array}{l}51.4 \\
61.4 \\
71.4^{4} \\
81.4 \\
91.4\end{array}$ & $\begin{array}{l}38.7 \\
54.8 \\
64.5 \\
87.1 \\
96.7\end{array}$ & $\begin{array}{l}38.3-39.1 \\
54.4-55.2 \\
64.2-64.8 \\
87.9-87.3 \\
96.6-96.8\end{array}$ & $\begin{array}{l}91.3 \\
78.5 \\
64.5 \\
50.4 \\
31.8\end{array}$ & $\begin{array}{l}91.1-91.5 \\
78.2-78.8 \\
64.2-64.8 \\
50.0-50.1 \\
31.5-32.1\end{array}$ & $\begin{array}{l}4.5 \\
2.6 \\
1.8 \\
1.8 \\
1.4\end{array}$ \\
\hline
\end{tabular}

${ }^{1} \mathrm{Se}=$ epidemiologic sensitivity.

${ }^{2} \mathrm{Sp}=$ epidemiologic specificity.

${ }^{3} \mathrm{LR}+=$ likelihood ratio positive.

${ }^{4}$ Highest combined Sp and Se (mEq/L).

${ }^{5}$ Includes retained placenta and metritis. 
or milk fever (Horst, 1986). Hypocalcemia is associated with recumbency, inappetence, lower productivity, and increases risk of other transition diseases (Erb et al., 1985; Chapinal et al., 2012). Calcium is also integral to keratinization process for hoof and horn development (Tomlinson et al., 2004).

Vitamin $\mathrm{D}_{3}$ feed supplementation was negatively correlated with serum $25(\mathrm{OH}) \mathrm{D}$ concentrations at the farm level in this study. We did not measure DCAD, which affects mineral metabolism. A negative DCAD improved serum vitamin D concentrations of cows supplemented with vitamin $\mathrm{D}$ (vitamin $\mathrm{D}_{3}$ and calcidiol; Weiss et al., 2015; Rodney et al., 2018). Future studies should measure DMI and consider DCAD, so the amount of vitamin D ingested and absorbed by each cow is known.

The dairy cattle in our study had serum $25(\mathrm{OH}) \mathrm{D}$ concentrations higher than those previously reported in dairy cattle. Sorge et al. (2013) reported a mean concentration of $62.5 \mathrm{ng} / \mathrm{mL}$ and Nelson et al. (2016) reported a mean concentration of $68 \mathrm{ng} / \mathrm{mL}$. The overall mean serum $25(\mathrm{OH}) \mathrm{D}$ is our sample was $90.2 \mathrm{ng} /$ ml. This discrepancy could potentially be attributed to laboratory or assay variation, which is a common issue for serum $25(\mathrm{OH}) \mathrm{D}$ measurement in both humans and animals (Binkley and Carter, 2017). Circulating $25(\mathrm{OH}) \mathrm{D}$ concentrations are genotype-dependent, which makes it more difficult to compare concentrations between cows that may already have different baseline serum 25(OH)D concentrations (Casas et al., 2013). If the cows in this study truly have higher serum $25(\mathrm{OH}) \mathrm{D}$ concentrations compared with concentrations previously reported, it could potentially be due to over-supplementation. Sacco et al. (2012) used an experimental infection model with bovine respiratory syncytial virus to compare calves with low, normal, and high vitamin D statuses. High vitamin D calves had enhanced expression of a pro-inflammatory cytokine (IL-8) and had differential expression of other cytokines compared with control calves (Sacco et al., 2012).

The study has limitations that should be addressed. The study was conducted among well-managed herds that had low disease incidence, which could be a potential reason why we found mixed results for the association between serum 25(OH)D and lameness. Because serum $25(\mathrm{OH}) \mathrm{D}$ is a regulator of calcium homeostasis, it thereby affects the keratinization process, which can lead to poor hoof quality and a higher incidence of lame cows (Tomlinson et al., 2004). Low serum 25(OH)D has been linked to lameness and pelvic fracture in other studies (Mülling et al., 1999; NRC, 2001). In the descriptive analyses in the present study, serum $25(\mathrm{OH}) \mathrm{D}$ at dry-off and close-up was significantly lower in those that developed lameness. In the logistic regression analyses that included an adjustment for correlation between farms (i.e., random intercept), serum $25(\mathrm{OH})$ D concentrations were no longer associated with lameness. This was most likely because the majority of lameness cases $(n=17 / 19)$ were from the same farm. Future studies should investigate the predictability of serum 25(OH)D for lameness. Another limitation in the present study was that we only had information concerning the presence of ketones in the urine and precise diagnostic information relating to subclinical or clinical ketosis was not available. Future studies should investigate the predictive value of serum $25(\mathrm{OH}) \mathrm{D}$ concentrations for ketosis, so that cows at risk for both subclinical and clinical ketosis can be identified.

\section{CONCLUSIONS}

We found that serum $25(\mathrm{OH}) \mathrm{D}$ concentrations measured at dry-off and close-up predicted increased urine ketone concentrations in early lactation dairy cows. We also found that serum $25(\mathrm{OH}) \mathrm{D}$ concentrations at $2-10$ DIM were associated with uterine disorders (metritis and retained placenta). The next research step is to confirm these findings in more diverse herds (i.e., with different levels of vitamin D supplementation, higher disease incidence, or different geographical locations). If serum $25(\mathrm{OH}) \mathrm{D}$ concentrations prove to be an accurate biomarker for health disorders as early as dryoff, this leaves time to implement strategies to prevent development of disease around calving. Future studies should also determine how both ingested and absorbed vitamin D through supplementation affects serum $25(\mathrm{OH}) \mathrm{D}$ and disease risk.

\section{ACKNOWLEDGMENTS}

This study was funded, in part, by support from the Agriculture and Food Research Initiative Competitive Grants Program (2014-68004-21972 and 2017-6701526676) from the USDA National Institute of Food and Agriculture (NIFA), an endowment from the Matilda R. Wilson Fund (Detroit, MI).

\section{REFERENCES}

Binkley, N., and G. D. Carter. 2017. Toward clarity in clinical vitamin D status assessment: $25(\mathrm{OH}) \mathrm{D}$ assay standardization. Endocrinol. Metab. Clin. North Am. 46:885-899. https://doi.org/10.1016/j.ecl 2017.07.012.

Bursac, Z., C. H. Gauss, D. K. Williams, and D. W. Hosmer. 2008. Purposeful selection of variables in logistic regression. Source Code Biol. Med. 3:17. https://doi.org/10.1186/1751-0473-3-17.

Casas, E., R. J. Leach, T. A. Reinhardt, R. M. Thallman, J. D. Lippolis, G. L. Bennett, and L. A. Kuehn. 2013. A genomewide associa- 
tion study identified CYP2J2 as a gene controlling serum vitamin D status in beef cattle. J. Anim. Sci. 91:3549-3556. https://doi .org/10.2527/jas.2012-6020.

Chapinal, N., M. E. Carson, S. J. LeBlanc, K. E. Leslie, S. Godden, M. Capel, J. E. P. Santos, M. W. Overton, and T. F. Duffield. 2012. The association of serum metabolites in the transition period with milk production and early-lactation reproductive performance. J. Dairy Sci. 95:1301-1309. https://doi.org/10.3168/jds.2011-4724.

Curtis, C. R., H. N. Erb, C. J. Sniffen, R. D. Smith, P. A. Powers, M. C. Smith, M. E. White, R. B. Hillman, and E. J. Pearson. 1983. Association of parturient hypocalcemia with eight periparturient disorders in Holstein cows. JAVMA 183:559-561.

DeGaris, P. J., and I. J. Lean. 2008. Milk fever in dairy cows: A review of pathophysiology and control principles. Vet. J. 176:58-69.

Dohoo, I., W. Martin, and H. Stryhn. 2012. Methods in Epidemiologic Research. VER Inc., Charlottetown, Prince Edward Island, Canada.

Duffield, T. 2000. Subclinical ketosis in lactating dairy cattle. Vet. Clin. North Am. Food Anim. Pract. 16:231-253.

Erb, H. N., R. D. Smith, P. A. Oltenacu, C. L. Guard, R. B. Hillman, P. A. Powers, M. C. Smith, and M. E. White. 1985. Path model of reproductive disorders and performance, milk fever, mastitis, milk yield, and culling in Holstein cows. J. Dairy Sci. 68:3337-3349.

Farrell, C. J., S. Martin, B. McWhinney, I. Straub, P. Williams, and M. Herrmann. 2012. State of-the-art vitamin D assays: A comparison of automated immunoassays with liquid chromatography tandem mass spectrometry methods. Clin. Chem. 58:531-542.

Gast, D. R., R. L. Horst, N. A. Jorgensen, and H. F. DeLuca. 1979. Potential use of 1,25 dihydroxycholecalciferol for prevention of parturient paresis. J. Dairy Sci. 62:1009-1013.

Goff, J. P. 2006. Major advances in our understanding of nutritional influences on bovine health. J. Dairy Sci. 89:1292-1301.

Goff, J. P. 2008. The monitoring, prevention, and treatment of milk fever and subclinical hypocalcemia in dairy cows. Vet. J. 176:50-57.

Goff, J. P., T. A. Reinhardt, and R. L. Horst. 1991. Enzymes and factors controlling vitamin D metabolism and action in normal and milk fever cows. J. Dairy Sci. 74:4022-4032.

Greiner, M., D. Pfeiffer, and R. D. Smith. 2000. Principles and practical application of the receiver-operating characteristic analysis for diagnostic tests. Prev. Vet. Med. 45:23-41.

Gröhn, Y. T., H. N. Erb, C. E. McCulloch, and H. S. Saloniemi. 1990. Epidemiology of reproductive disorders in dairy cattle: Associations among host characteristics, disease and production. Prev. Vet. Med. 8:25-39.

Herdt, T. H., and H. D. Stowe. 1991. Fat-soluble vitamin nutrition for dairy cattle. Vet. Clin. North Am. Food Anim. Pract. 7:391-415.

Hibbs, J. W., and H. R. Conrad. 1983. The relation of calcium and phosphorus intake and digestion and the effects of vitamin $\mathrm{D}$ feeding on the utilization of calcium and phosphorus by lactating dairy cows. Research Bulletin 1150. Ohio Agricultural Research and Development Center, The Ohio State University, Wooster.

Holcombe, S. J., L. Wisnieski, J. Gandy, B. Norby, and L. M. Sordillo. 2018. Reduced serum vitamin D concentrations in health early-lactation dairy cattle. J. Dairy Sci. 101:1488-1494. https:// doi.org/10.3168/jds.2017-13547.

Horst, R. L. 1986. Regulation of calcium and phosphorus homeostasis in the dairy cow. J. Dairy Sci. 69:604-616.

Horst, R. L., J. P. Goff, and T. A. Reinhardt. 1994. Calcium and vitamin D metabolism in the dairy cow. J. Dairy Sci. 77:1936-1951.

Hosmer, D. W., S. Lemeshow, and R. X. Sturdivant. 2013. Applied Logistic Regression. 3rd ed. John Wiley and Sons Inc., Hoboken, NJ.

Kristensen, T. 1986. Method for estimation of body condition of dairy cows. Rep. no. 615. Natl. Inst. Anim. Sci. Pages 59-75. Fredriksberg, Denmark.

Lippolis, J. D., T. A. Reinhardt, R. A. Sacco, B. J. Nonnecke, and C. D. Nelson. 2011. Treatment of an intramammary bacterial infection with 25-hydroxyvitamin $\mathrm{D}_{3}$. PLoS One 6:e25479. 10.1371/ journal.pone.0025479.

Martinez, N., C. A. Risco, F. S. Lima, R. S. Bisinotto, L. F. Greco, E. S. Ribeiro, F. Maunsell, K. Galvão, and J. E. P. Santos. 2012.
Evaluation of peripartal calcium status, energetic profile, and neutrophil function in dairy cows at low or high risk of developing uterine disease. J. Dairy Sci. 95:7158-7172. https://doi.org/10 $.3168 /$ jds.2012-5812.

Martinez, N., R. M. Rodney, E. Block, L. L. Hernandez, C. D. Nelson, I. J. Lean, and J. E. P. Santos. 2018. Effects of prepartum dietary cation-anion difference and source of vitamin D in dairy cows: Health and reproductive responses. J. Dairy Sci. 101:2563-2578. https://doi.org/10.3168/jds.2017-13740.

Martinez, N., L. D. P. Sinedino, R. S. Bisinotto, E. S. Ribeiro, G. C. Gomes, F. S. Lima, L. F. Greco, C. A. Risco, K. N. Galvão, D. Taylor-Rodriguez, J. P. Driver, W. W. Thatcher, and J. E. P. Santos. 2014. Effect of induced subclinical hypocalcemia on physiological responses and neutrophil function in dairy cows. J. Dairy Sci. 97:874-887. https://doi.org/10.3168/jds.2013-7408.

McArt, J. A. A., D. V. Nydam, and G. R. Oetzel. 2012. Epidemiology of subclinical ketosis in early lactation dairy cattle. J. Dairy Sci. 95:5056-5066.

Miller, W. J. 1979. Sources and metabolism of vitamin D. Pages 193195 in Dairy Cattle Feed and Nutrition. Acad. Press Inc., New York, NY.

Mülling, C. K., H. H. Bragulla, S. Reese, K. D. Budras, and W. Steinberg. 1999. How structures in bovine hoof epidermis are influenced by nutritional factors. Anat. Hist. Embry. 28:103-108.

National Research Council (NRC). 2001. Nutrient Requirements of Dairy Cattle. 7th rev. ed. Natl. Acad. Press, Washington, DC.

Nelson, C. D., J. D. Lippolis, T. A. Reinhardt, R. E. Sacco, J. L. Powell, M. E. Drewnoski, M. O'Neil, D. C. Beitz, and W. P. Weiss. 2016. Vitamin D status of dairy cattle: Outcomes of current practices in the dairy industry. J. Dairy Sci. 99:10150-10160. https:// doi.org/10.3168/jds.2016-11727.

Nelson, C. D., B. J. Nonnecke, T. A. Reinhardt, W. R. Waters, D. C. Beitz, and J. D. Lippolis. 2011. Regulation of Mycobacterium-Specific Mononuclear cell responses by 25 hydroxyvitamin $\mathrm{D}_{3}$. PLoS One 6:e21674. https://doi.org/10.1371/journal.pone.0021674.

Nelson, C. D., T. A. Reinhardt, D. C. Beitz, and J. D. Lippolis. 2010. In vivo activation of the intracrine vitamin $\mathrm{D}$ pathway in innate immune cells and mammary tissue during a bacterial infection. PLoS One 5:e15469. https://doi.org/10.1371/journal.pone.0015469.

Neves, R. C., B. M. Leno, K. D. Bach, and J. A. A. McArt. 2018. Epidemiology of subclinical hypocalcemia in early-lactation Holstein dairy cows: the temporal associations of plasma calcium concentration in the first 4 days in milk with disease and milk production. J. Dairy Sci. 101:9321-9331. https://doi.org/10.3168/jds.2018-14587.

Nonnecke, B. J., J. L. McGill, J. F. Ridpath, R. E. Sacco, J. D. Lippolis, and T. A. Reinhardt. 2014. Acute phase response elicited by experimental bovine diarrhea virus (BVDV) infection is associated with decreased vitamin $\mathrm{D}$ and $\mathrm{E}$ status of vitamin-replete preruminant calves. J. Dairy Sci. 97:5566-5579. https://doi.org/10.3168/ jds.2014-8293.

Reichenheim, M. E. 2002. Two-graph receiver operating characteristic. Stata J. 2:351-357.

Rodney, R. M., P. Celi, J. J. McGrath, H. M. Golder, S. T. Anderson, D. M. McNeill, D. R. Fraser, and I. J. Lean. 2019. Metabolic and production responses to calcidiol treatment in mid lactation dairy cows. Anim. Prod. Sci. 59:449-460. https://doi.org/10.1071/ AN16770.

Rodney, R. M., N. Martinez, E. Block, L. L. Hernandez, P. Celi, C. D. Nelson, J. E. P. Santos, and I. J. Lean. 2018. Effects of prepartum dietary cation-anion difference and source of vitamin D in dairy cows: Vitamin D, mineral, and bone metabolism. J. Dairy Sci. 101:2519-2543. https://doi.org/10.3168/jds.2017-13737.

Sacco, R. E., B. J. Nonnecke, M. V. Palmer, W. R. Waters, J. D. Lippolis, and T. A. Reinhardt. 2012. Differential expression of cytokines in response to respiratory syncytial virus infection of calves with high or low circulating 25-hydroxyvitamin $\mathrm{D}_{3}$. PLoS One 7:e33074. https://doi.org/10.1371/journal.pone.0033074.

Sachs, M., A. Bar, R. Cohen, Y. Mazur, E. Mayer, and S. Hurwitz. 1977. Use of 1alpha hydroxycholecalciferol in the prevention of bovine parturient paresis. Am. J. Vet. Res. 38:2039-2041. 
Sorge, U. S., T. Molitor, J. Linn, D. Gallaher, and S. W. Wells. 2013. Cow-level association between serum 25-hydroxyvitamin D concentration and Mycobacterium avium subspecies paratuberculosis antibody seropositivity: A pilot study. J. Dairy Sci. 96:1030-1037. https://doi.org/10.3168/jds.2012-5929.

StataCorp. 2015. Stata Statistical Software: Release 14. StataCorp LP, College Station, TX

Steingrimsdottir, L., O. Gunnarsson, O. S. Indridason, L. Franzson, and G. Sigurdsson. 2005. Relationship between serum parathyroid hormone levels, vitamin D sufficiency, and calcium intake. JAMA 294:2336-2341.

Téllez-Pérez, A. D., N. Alva-Murillo, A. Ochoa-Zarzosa, and J. E. López-Meza. 2012. Cholecalciferol (vitamin D) differentially regulates antimicrobial peptide expression in bovine mammary epithelial cells: Implications during Staphylococcus aureus internalization. Vet. Microbiol. 160:91-98. https://doi.org/10.1016/j.vetmic 2012.05.007

Tomlinson, D. J., C. H. Mülling, and T. M. Fakler. 2004. Invited Review: Formation of keratins in the bovine claw: Roles of hormones, minerals, and vitamins in functional claw integrity. J. Dairy Sci. 87:797-809.

Wallis, G. C. 1938. Some effects of vitamin D deficiency of mature dairy cows. J. Dairy Sci. 21:315.

Waters, W. R., B. J. Nonnecke, M. R. Foote, A. C. Maue, T. E. Rahner, M. V. Palmer, D. L. Whipple, R. L. Horst, and D. M.
Estes. 2003. Mycobacterium bovis bacille Calmette Guerin vaccination of cattle: activation of bovine $\mathrm{CD}^{+}$and $\gamma \delta \mathrm{TCR}^{+}$cells and modulation by 1,25-dihydroxyvitamin $\mathrm{D}_{3}$. Tuberculosis (Edinb.) 83:287-297. https://doi.org/10.1016/S1472-9792(03)00002-7.

Weiss, W. P., E. Azem, W. Steinburg, and T. A. Reinhardt. 2015. Effect of feeding 25 hydroxyvitamin $\mathrm{D}_{3}$ with a negative cation-anion difference diet on calcium and vitamin D status of periparturient cows and their calves. J. Dairy Sci. 98:5588-5600. https://doi.org/ 10.3168/jds.2014-9188.

Wisnieski, L., B. Norby, S. J. Pierce, T. Becker, J. C. Gandy, and L. M. Sordillo. 2019. Predictive models for early lactation diseases in transition dairy cattle at dry-off. Prev. Vet. Med. 163:68-78. https: //doi.org/10.1016/j.prevetmed.2018.12.014.

\section{ORCIDS}

J. L. Brown ( https://orcid.org/0000-0001-6399-4864

S. J. Holcombe @ https://orcid.org/0000-0002-3235-1249

J. C. Gandy ๑ https://orcid.org/0000-0003-0558-9611

L. M. Sordillo $\odot$ https://orcid.org/0000-0001-8873-3134 